\title{
The Potential of Vibrational Spectroscopy in the Early Detection of Cervical Cancer: an Exciting Emerging Field
}

\author{
Eoghan O'Faolain \\ Technological University Dublin, Eoghan.ofaolain@tudublin.ie \\ Mary Hunter \\ National Maternity Hospital, Holles Street, Dublin \\ Joe Byrne \\ National Maternity Hospital, Holles Street, Dublin
}

See next page for additional authors

Follow this and additional works at: https://arrow.tudublin.ie/radcon

Part of the Physics Commons

\section{Recommended Citation}

O'Faolain, E., Hunter, M.B. \& Byrne, J.M. (2005). The potential of vibrational spectroscopy in the early detection of cervical cancer: an exciting emerging field. Proceedings of Optolreland SPIE, vol. 5826, pg.25. doi:10.1117/12.603344

This Conference Paper is brought to you for free and open access by the Radiation and Environmental Science Centre at ARROW@TU Dublin. It has been accepted for inclusion in Conference papers by an authorized administrator of ARROW@TU Dublin. For more information, please contact arrow.admin@tudublin.ie, aisling.coyne@tudublin.ie,gerard.connolly@tudublin.ie.

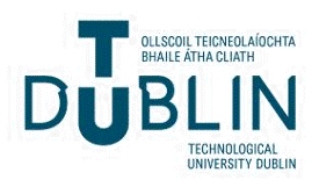


Authors

Eoghan O'Faolain, Mary Hunter, Joe Byrne, Peter Kelehan, Hugh Byrne, and Fiona Lyng

This conference paper is available at ARROW@TU Dublin: https://arrow.tudublin.ie/radcon/4 


\title{
The potential of vibrational spectroscopy in the early detection of cervical cancer: an exciting emerging field
}

\author{
Eoghan Ó Faoláin* a, b , Mary B. Hunter ${ }^{\mathrm{c}}$, Joe M. Byrne ${ }^{\mathrm{c}}$, Peter Kelehan ${ }^{\mathrm{d}}$, Hugh J. Byrne ${ }^{\mathrm{a}}$, \\ Fiona M. Lyng a, e \\ ${ }^{a}$ Focas Institute, Dublin Institute of Technology, Kevin St., Dublin 8 \\ ${ }^{\mathrm{b}}$ School of Physics, Dublin Institute of Technology, Kevin St., Dublin 8 \\ ${ }^{c}$ Department of Histology, National Maternity Hospital, Holles St., Dublin 2 \\ ${ }^{\mathrm{d}}$ Dept. of Pathology and Laboratory Medicine, NMH, Holles St., Dublin 2 \\ ${ }^{\mathrm{e}}$ Radiation and Environmental Science Centre (RESC), Focas Institute, Dublin Institute of \\ Technology, Kevin Street, Dublin 8
}

\begin{abstract}
The application of vibrational spectroscopy to disease diagnosis is a relatively new, rapidly evolving scientific field. Techniques such as Raman and infrared spectroscopy have shown great promise in this regard over the past number of years. This study directly compared Raman spectroscopy and synchrotron infrared (SR-IR) spectroscopy on parallel cervical cancer samples. Both frozen and dewaxed formalin fixed paraffin preserved tissue sections were examined. Both tissue types produced good quality Raman and SR-IR spectra, although the lesser processed, frozen tissue sections displayed the most detailed spectra. Spectroscopy was shown capable of discriminating between different cell types in normal cervical tissue. Spectra recorded from invasive carcinoma showed a marked difference from those recorded from normal cervical epithelial cells. Spectral differences identified with the onset of carcinogenesis include increased nucleic acid contributions and decreased glycogen levels. These investigations pave the way for an enlarged study into this exciting new diagnostic field.
\end{abstract}

Keywords: Raman spectroscopy, Fourier transform infrared spectroscopy, synchrotron radiation, cervix, cervical cancer, malignant, cancer diagnosis, cervical intraepithelial neoplasia.

\section{INTRODUCTION}

Just fewer than 20,000 people are annually diagnosed with some form of cancer in Ireland, and one in three of us are likely to contract some form of cancer by age 74. Globally this figure is estimated to exceed 8 million cancer cases per year, resulting in over 5 million deaths annually. With the number of cases increasing at an annual rate of $2 \%$, the early detection and treatment of cancer is becoming increasingly important. The detection of dysplasia and early cancer is vital because of the increased survival rates associated with early treatment. In recent years, because of the success of vibrational spectroscopy in biological applications, its potential for the study and diagnosis of disease has been recognised ${ }^{1}$. Both IR and Raman spectroscopy offer the potential for real time, quantitative detection of cancer and even precancer. Spectroscopy is an analytical, non-destructive technique, which provides information about the molecular structure of the investigated sample. The positions, intensities and linewidths of both IR and Raman spectral lines, yield information about the composition, secondary structure, and interaction of molecules within the sample. This study investigated the potential of Raman, and synchrotron Fourier transform infrared (SR-FTIR) spectroscopy in the detection of cervical cancer. This rapidly evolving interface between physical sciences and the area broadly termed "biochemical sciences", offers exciting opportunities to better understand and detect disease early on a cellular level.

Vibrational spectroscopy can provide important structural information on the molecular composition of a sample. Biomedical samples contain a mixture of proteins, nucleic acids and carbohydrates. Infrared and Raman bands frequently found in such samples include the amide I band resulting mainly from $\mathrm{C}=\mathrm{O}$ stretching vibrations of proteins, the amide II band, resulting from $\mathrm{N}-\mathrm{H}$ bending vibrations of proteins, the $\mathrm{C}=\mathrm{O}$ stretching of lipids and the anti symmetric $\mathrm{PO}_{2}$ stretching of nucleic acids and phospholipids. 
Raman spectroscopy is a vibrational spectroscopy based on inelastic light scattering. Raman scattering results from the variation of the polarisability of the molecule as it vibrates. The sample is illuminated by monochromatic laser light and interactions between the incident photons and molecules in the sample result in scattering of the light. A defined amount of energy is transferred from the photon to the molecule in which a vibrational mode is excited. The exact energy required to excite a molecular vibration depends on the masses of the atoms involved in the vibration and the type of chemical bonds between these atoms and may be influenced by molecular structure, molecular interactions and the chemical microenvironment of the molecule. Therefore, the positions, relative intensities and shapes of the bands in a Raman spectrum carry detailed information about the molecular composition of the sample.

Infrared (IR) spectroscopy is a vibrational spectroscopy widely used to obtain information about the composition of materials through variations in the absorption of IR light across a broad frequency range. In IR spectroscopy, resonance occurs between the electromagnetic radiation illuminating the sample and the oscillating dipole of the molecular vibration. If the molecular dipole doesn't vary, no resonance takes place and therefore no absorption of the mid infrared radiation. The mid IR range $\left(400-4000 \mathrm{~cm}^{-1}\right)$ of an absorption spectrum contains features relating to the vibrational absorption of molecular bonds within the sample.

Conventional FTIR spectrometers use blackbody sources, such as a tungsten-halide lamp to generate the excitation radiation. In synchrotron sources, electromagnetic radiation is emitted tangentially by electrons moving at relativistic speed in a circular storage ring and accelerated by means of bending magnets. The advantages associated with the use of synchrotron radiation for infrared (IR) spectroscopic measurements include the provision of a small effective source size, and low thermal noise (due to the low-divergence beam from the IR synchrotron source). This results in a stable, highly collimated beam produced at the experimental station ${ }^{2}$. The recent development of FTIR capabilities at synchrotron laboratories has facilitated the study of biological samples about $5-20 \mu \mathrm{m}$ in dimensions ${ }^{3}$, with a beam up to 100 times more intense and of higher signal-to-noise ratio than is possible using a conventional IR source ${ }^{4}$.

Some vibrational motions give rise to infrared absorption, some to Raman bands and some to both, but in the latter case the intensities of the interactions would not be the same in each spectrum. Therefore Raman and FTIR are complementary spectroscopic methods used to measure the vibrational and rotational frequencies because different selection rules are obeyed. However, Raman spectroscopy has the particular advantage over infrared spectroscopy that there is only a small interference from water, making it uniquely suited to the study of biological material.

In the last ten years there has been considerable progress in the application of infrared spectroscopy to the analysis of human tissues in the context of disease diagnosis. It has been convincingly demonstrated in many studies that infrared spectroscopy can be used to classify tissues as normal or pathological. Comprehensive reviews of the field have been published recently ${ }^{5,6}$. There have been a number of publications on IR spectroscopic studies of cervical tissues ${ }^{7,8,9}$ and exfoliated cervical cells or cervical smears ${ }^{10,11,12}$. The main findings have been that IR spectra from normal cells exhibit intense glycogen bands whereas tumour cells exhibit pronounced nucleic acid bands and a reduction in the intensity of the glycogen bands. Raman spectroscopy has been used in the detection of a variety of cancers including breast ${ }^{13}$, skin ${ }^{14}$, lung ${ }^{15}$, brain ${ }^{16}$, liver ${ }^{17}$ and prostate ${ }^{18}$. There has only been a limited amount of research into cervical tissue samples 19,20 . Decreases in peaks associated with collagen and increases in peaks associated with phospholipids and DNA were reported.

This preliminary study seeks to compare the Raman and SR-FTIR spectra obtained from different cervical cell types from both frozen and fixed cervical tissue sections. It aims to investigate whether normal cervical tissue can be discriminated from invasive carcinoma, and whether vibrational spectroscopy is capable of highlighting premalignant changes. 


\section{METHODOLOGY}

\subsection{Instrumentation:}

Synchrotron FT-IR measurements were taken at the 11.1 beamline at the synchrotron radiation source (SRS), Daresbury Laboratory, Cheshire, England. The beam is extracted from a storage ring of current $\sim 250 \mathrm{~mA}$ at $\sim 2 \mathrm{GeV}$. The station utilises an FT-IR microscope (Nicolet Nexus FT-IR spectrometer and a Nicolet Continu $\mu$ m IR-microscope, ThermoNicolet Inc., Madison, USA) interfaced to the beamline exit port. The beamline is deflected using a series of mirrors, including a cooled mirror in the plane of the ring, so as to enter the spectrometer ${ }^{2}$. A Spectra-Tech $32 \mathrm{X}$ Reflachromat objective $(0.65$ N.A. and $8 \mathrm{~mm}$ working distance) was used throughout. Various parameters were investigated to obtain a satisfactory spectrum. The microscope aperture was set to $10 \mu \mathrm{m} \times 10 \mu \mathrm{m}$, and 128 scans with an $8 \mathrm{~cm}^{-1}$ resolution yielded good quality spectra.

Due to the fact that glass absorbs in the IR region, regular glass slides were not suitable for mounting tissue sections. IR reflective slides (MirrIR) were obtained from Kevley Technologies (Chesterland, Ohio, USA). MirrIR microscope slides reflect $95 \%$ of mid-IR radiation with no interfering absorption or mathematical corrections, and spectra are obtained in the reflective mode (effectively a double pass transmission) with a simple focus and scan procedure. The MirrIR slides were evaluated for deterioration resulting from exposure to chemicals used in the dewaxing process, and minimal deterioration in its IR reflective properties was found.

An Instruments S.A. Labram 1B Raman spectroscopic confocal microscope was used, with an Argon Ion laser operating at a wavelength of $514.5 \mathrm{~nm}$. The Labram imaging system is a fully confocal Raman microscope system, with a motorised XY sample stage for automated Raman imaging. The system includes a stigmatic spectrometer with two motorised gratings, of which the 1800 grooves/mm grating was used. The resolution of the system operating with the 1800 grooves $/ \mathrm{mm}$ was $1.65 \mathrm{~cm}^{-1} /$ pixel. Detection of the scattered light was performed using a Peltier cooled, 16-bit dynamic range CCD detector with $1024 \times 256$ pixels. A x50 objective lens was used. The laser power at the sample was measured and found to be $\sim 6.5 \pm 0.05 \mathrm{~mW}$, focused to a spot size of $\sim 2 \mu \mathrm{m}$ at the tissue surface. The scattered Raman signal was integrated for 60 to 150 seconds and measured over a spectral range of 400 to $1900 \mathrm{~cm}^{-1}$ with respect to the excitation frequency. Once acquired each spectrum was baseline corrected, noise subtracted, and lightly filtered using a third order linear model to improve clarity.

\subsection{Sample preparation (FFPP sections):}

12 formalin fixed paraffin processed (FFPP) cervical tissue sections were obtained from the National Maternity Hospital (NMH), Holles Street, Dublin. As characterised by the registrar the samples received consisted of 4 normal, 5 invasive carcinoma, and 3 dypslasia. After the wax impregnation, tissue was embedded and sliced into $5 \mu \mathrm{m}$ sections, mounted on MirrIR slides and dried. Two sections were taken from each sample. The sections were immersed in a series of baths consisting of two baths of xylene (BDH, Dorset, UK) for five minutes and four minutes respectively, two baths of ethanol absolut (Merck, Dorset, UK) for three minutes and two minutes, and a final bath of industrial methylated spirits 95\% (Lennox, Dublin, Ireland) for one minute. One section from each sample (the reference section) was stained with haematoxylin and eosin, and the other kept unstained for spectroscopic examination.

\subsection{Sample preparation (Frozen sections):}

4 normal cervix "unprocessed" tissue sections were obtained from NMH Holles St. These sections were not formalin fixed and were not embedded in wax. Tissue samples were placed on a metal chuck with OCT (optimum cutting temperature) as a support medium, and placed in a cryostat. A metal heat trap was used for heat exchange to bring the tissue to a temperature of $-20^{\circ} \mathrm{C}$. Tissue sections were cut using the cryostats' internal microtome. Tissue sections were then mounted on MirrIR slides and air-dried. Again a reference section was stained in haematoxylin and eosin, and the other was kept in its unstained state for spectroscopic investigation. 


\begin{tabular}{|c|c|}
\hline $\begin{array}{l}\text { Approximate } \\
\text { Frequency } \\
\left(\mathrm{cm}^{-1}\right)\end{array}$ & Assignment \\
\hline 3500 & O-H str of hydroxyl groups \\
\hline 3200 & N-H str (Amide A) of proteins \\
\hline 2959 & $\begin{array}{l}\mathrm{C}-\mathrm{H} \text { str }(\text { asym }) \text { of }-\mathrm{CH}_{3} \\
\text { methyl }\end{array}$ \\
\hline 2934 & $\begin{array}{l}\mathrm{C}-\mathrm{H} \text { str }(\text { asym }) \text { of }>\mathrm{CH}_{2} \\
\text { methylene }\end{array}$ \\
\hline 2921 & $\begin{array}{l}\mathrm{C}-\mathrm{H} \text { str (asym) of }>\mathrm{CH}_{2} \\
\text { methylene in fatty acids }\end{array}$ \\
\hline 2898 & $\mathrm{C}-\mathrm{H}$ str of methine \\
\hline 2872 & $\mathrm{C}-\mathrm{H}$ str (sym) of $-\mathrm{CH}_{3}$ methyl \\
\hline 2852 & $\begin{array}{l}\mathrm{C}-\mathrm{H} \text { str (asym) of }>\mathrm{CH}_{2} \\
\text { methylene in fatty acids }\end{array}$ \\
\hline 1741 & $>\mathrm{C}=\mathrm{O}$ str of esters \\
\hline 1715 & $\begin{array}{l}>\mathrm{C}=\mathrm{O} \text { str of ester, protonated } \\
\text { carboxyl and carbonyl groups }\end{array}$ \\
\hline 1695 & different amide I band \\
\hline 1685 & components resulting from \\
\hline 1675 & $\begin{array}{l}\text { antiparallel pleated sheets and } \\
\beta \text {-turns of proteins }\end{array}$ \\
\hline 1655 & amide I of $\alpha$-helical structures \\
\hline 1637 & $\begin{array}{l}\text { amide } 1 \text { of } \beta \text {-pleated sheet } \\
\text { structures }\end{array}$ \\
\hline 1548 & amide II band \\
\hline 1515 & tyrosine band \\
\hline 1468 & $\mathrm{C}-\mathrm{H}$ sc of $>\mathrm{CH}_{2}$ methylene \\
\hline 1400 & $\begin{array}{l}\mathrm{C}=\mathrm{O} \text { symmetric stretch of } \\
\mathrm{COO}^{-}\end{array}$ \\
\hline $1310-1240$ & $\begin{array}{l}\text { amide III band components of } \\
\text { proteins }\end{array}$ \\
\hline $1250-1220$ & $\begin{array}{l}\mathrm{P}=\mathrm{O} \text { str }(\text { asym }) \text { of }>\mathrm{PO}_{2}^{-} \\
\text {phosphodiesters }\end{array}$ \\
\hline $1088-1084$ & $\begin{array}{l}\mathrm{P}=\mathrm{O} \text { str }(\mathrm{sym}) \text { of }>\mathrm{PO}_{2}^{-} \\
\text {phosphodiesters }\end{array}$ \\
\hline $1200-900$ & $\begin{array}{l}\mathrm{C}-\mathrm{O}-\mathrm{C}, \mathrm{C}-\mathrm{O} \text { dominated by the } \\
\text { ring vibrations of } \\
\text { carbohydrates, } \\
\mathrm{C}-\mathrm{O}-\mathrm{P}, \mathrm{P}-\mathrm{O}-\mathrm{P}\end{array}$ \\
\hline 720 & $\begin{array}{l}\mathrm{C}-\mathrm{H} \text { rocking of }>\mathrm{CH}_{2} \\
\text { methylene }\end{array}$ \\
\hline
\end{tabular}

Table 1. Assignment of some of the spectral bands frequently found in FT-IR biological specimens ${ }^{22}$

\section{RESULTS AND DISCUSSION}

\subsection{SR-FTIR spectroscopy of FFPP cervical sections:}

Fig. 1 shows the spectra of three different cell types of dewaxed FFPP tissue sections from normal cervix. Spectra have been offset to facilitate clarity, and are shown over the entire spectral range $\left(400-4000 \mathrm{~cm}^{-1}\right)$. Contributions above $\approx 1800 \mathrm{~cm}^{-1}$ are mainly due to $\mathrm{CH}_{2}$ and $\mathrm{CH}_{3}$ stretching vibrations, which were found to fluctuate apparently randomly. The fingerprint region ranges from $800 \mathrm{~cm}^{-1}-1800 \mathrm{~cm}^{-1}$, and it is this region that will be closely examined in this study. A table outlining FT-IR assignments from a biological perspective is given in Table $1^{22}$.

Fig. 2 examines the "fingerprint region" of Fig 1 more closely. Spectra were recorded from a sample of normal cervix. The figure shows the infrared spectra of three classes of tissue, namely, connective tissue, basal cells and epithelial cells. Although over 40 spectra of each cell type were recorded only a representative selection are shown. The dominant assignments have been labelled on the graph for each of the three tissue types. The most obvious distinction between the different classes of tissue are the features exhibited by the epithelial cells in the $1100 \mathrm{~cm}^{-1}$ region. Three sharp peaks at $1036 \mathrm{~cm}^{-1}, 1079 \mathrm{~cm}^{-1}$ and $1152 \mathrm{~cm}^{-1}$ are present in normal epithelial cells.

The band at $1079 \mathrm{~cm}^{-1}$ originates from the symmetric stretch of phosphodiester groups of nucleic acids ${ }^{11}$. The bands at $1036 \mathrm{~cm}^{-}$ ${ }^{1}$ and $1152 \mathrm{~cm}^{-1}$ are attributable to glycogen ${ }^{7}$. They are derived mainly from vibrational modes of $\mathrm{CH}_{2} \mathrm{OH}$ groups of carbohydrates. Both the basal and epithelial cells display consistent spectra, whereas there appears to be quite a degree of variation among the connective tissue spectra. Strong amide I and amide II bands $\left(1654 \mathrm{~cm}^{-1}\right.$ and $1542 \mathrm{~cm}^{-1}$ respectively) are displayed by all three cell types, however, the amide I band of connective tissue appears to shift over a $10 \mathrm{~cm}^{-1}$ range. The amide I and II bands originate mainly from the vibrational mode of hydrogen-bonded amide groups of proteins ${ }^{21}$. C-H scissoring of $>\mathrm{CH}_{2}\left(1460 \mathrm{~cm}^{-1}\right), \mathrm{C}=\mathrm{O}$ symmetric stretch of $\mathrm{COO}^{-}(1397$ $\left.\mathrm{cm}^{-1}\right)$ and $\mathrm{P}=\mathrm{O}$ asymmetric stretching of $>\mathrm{PO}_{2}^{-}$phosphodiesters $\left(1236 \mathrm{~cm}^{-1}\right)$ are also present in all three categories ${ }^{22}$. 


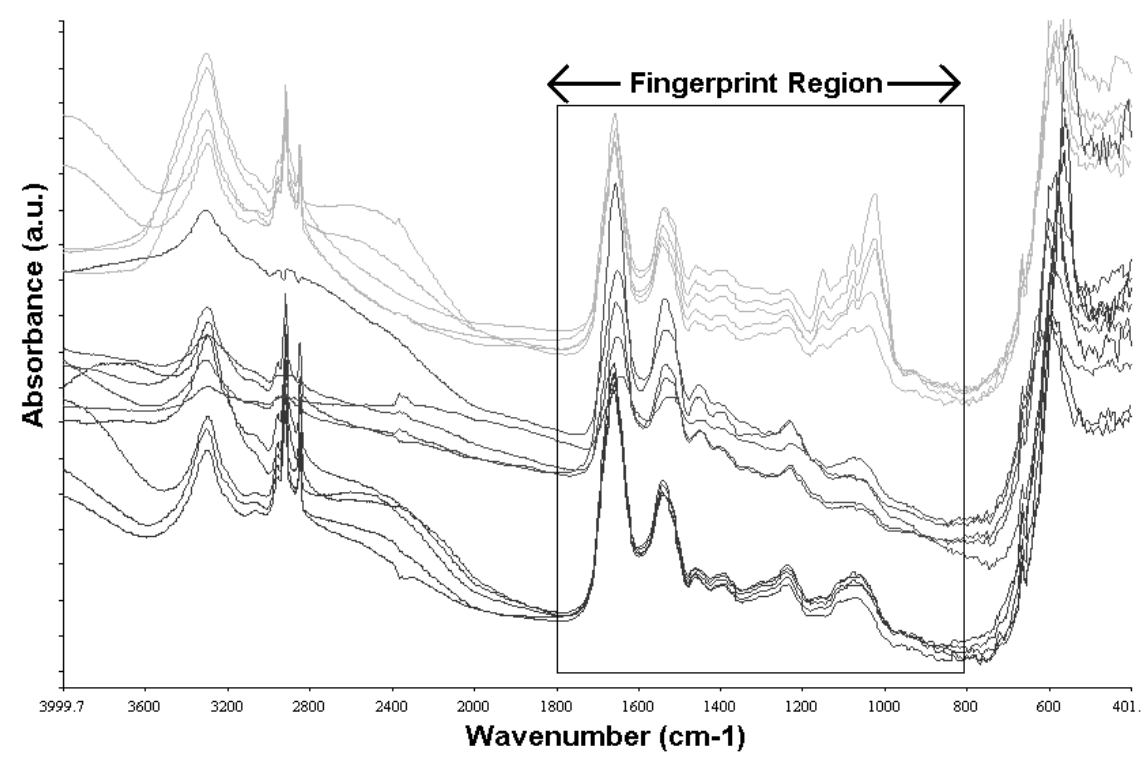

Fig. 1 FT-IR spectra of FFPP sections over the entire spectral range $\left(400-4000 \mathrm{~cm}^{-1}\right)$

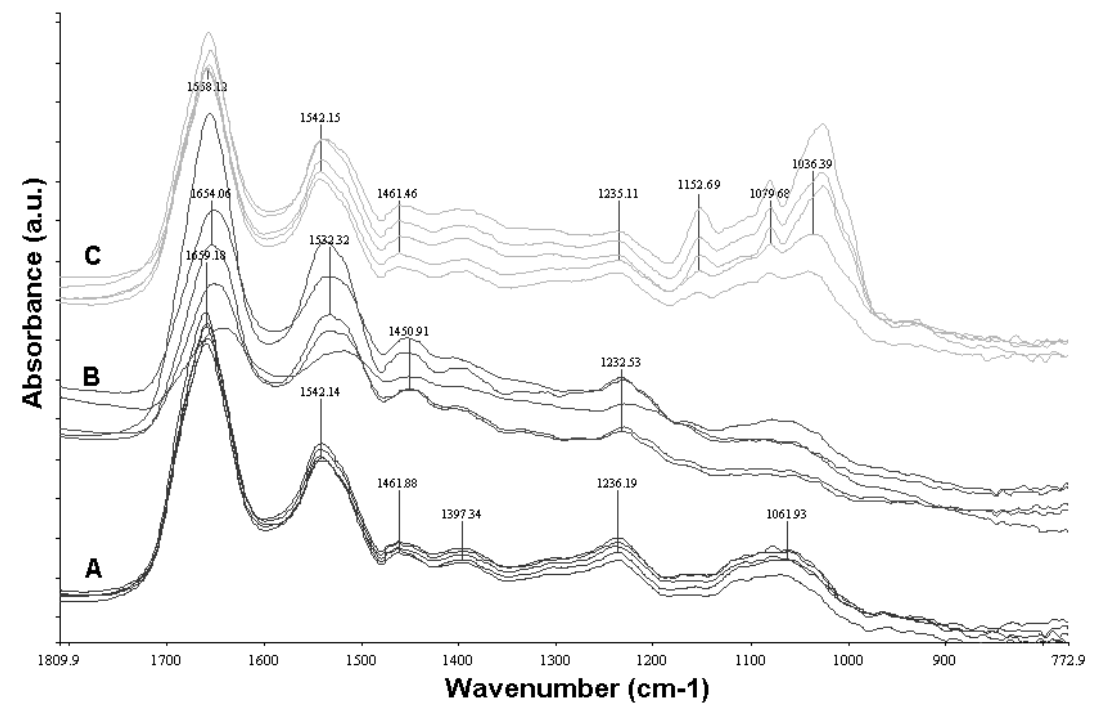

Fig. 2 Absorption spectra of A) basal cells B) connective tissue and C) epithelial cells

Fig. 3 shows a comparison of normal epithelial tissue spectrum to that of an invasive carcinoma taken from the same sample. There is a shift $\left(10 \mathrm{~cm}^{-1}\right)$ in the position of the amide I band between the two cell types, indicating a change in the $\alpha$-helical structure of the proteins. There is a dramatic decrease in the bands associated with glycogen $\left(1036 \mathrm{~cm}^{-1}\right.$ and $\left.1152 \mathrm{~cm}^{-1}\right)$. This reduction in glycogen has been observed in the literature ${ }^{8,12,21,23}$, and is to be expected due to the fact that glycogen levels increase in a cell as it ages. It is reasonable to assume that rapidly dividing cancer cells do not undergo the same ageing process as normal cells hence the glycogen differential. Also, an increase in the nucleic acid band at $1236 \mathrm{~cm}^{-1}$ occurs with the onset of carcinogenesis, which too could be expected due to rapidly dividing cells and has been quoted in literature ${ }^{7,23}$. Wong et. $a l^{7}$ and Sindhuphak et. al ${ }^{23}$ further observed an increase in the nucleic acid band at $1079 \mathrm{~cm}^{-1}$, however that increase has not been observed as dramatically in the samples examined in this study. Also, it was observed that there was a much more defined peak associated with the $\mathrm{CH}_{2}$ band at $1462 \mathrm{~cm}^{-1}$ in normal epithelial tissue. A noticeable characteristic of the infrared spectra of the invasive carcinoma is its similarity to the spectrum of basal cells in Fig. 2 - again to be expected as basal cells are proliferating in a manner similar to cancer cells. 


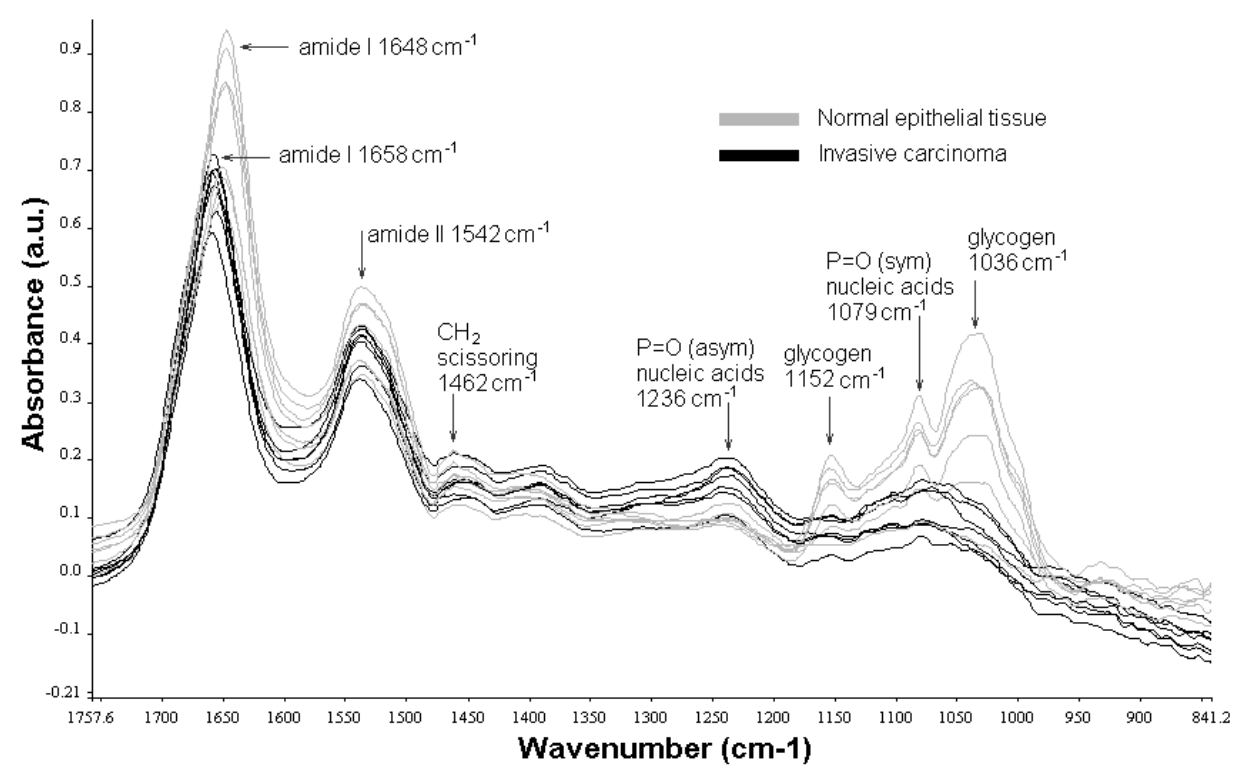

Fig. 3 FT-IR spectra of normal epithelial tissue and invasive carcinoma

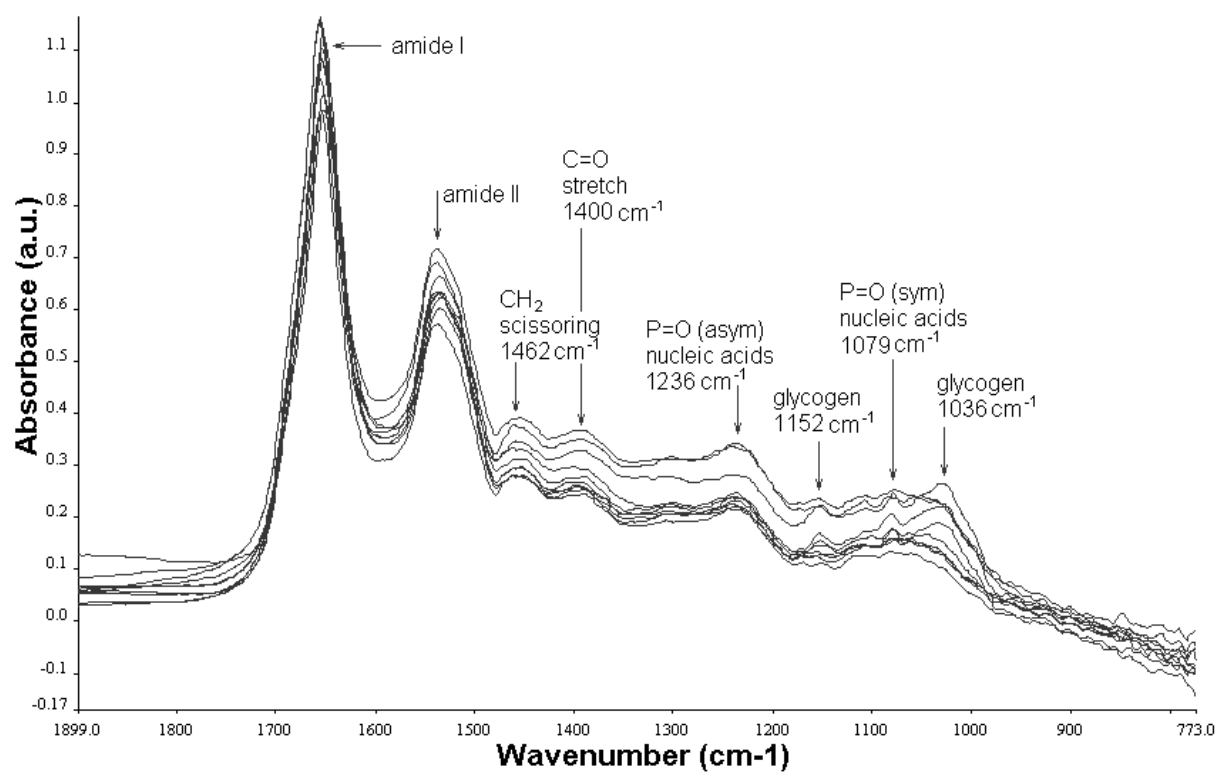

Fig. 4 FT-IR spectra of CIN III tissue

Fig. 4 shows the infrared spectra of a tissue section diagnosed as severe cervical intraepithelial neoplasia (CIN III). The important feature of pre-malignancy (CIN I, II and III) is that the abnormal cells are confined to the epithelium. The spectra of CIN III tissue is an amalgamation of the spectra of epithelial cells and tumour cells respectively. There is a significant reduction in the absorption due to glycogen $\left(1036 \mathrm{~cm}^{-1}\right.$ and $\left.1152 \mathrm{~cm}^{-1}\right)$, although amounts of glycogen are still present in approximately $30 \%$ of the points sampled. The other $70 \%$ of the spectra have little or no glycogen contribution. The nucleic acid absorption at $1236 \mathrm{~cm}^{-1}$ does not appear to vary within the sample.

Over 500 spectra were recorded from the 12 dewaxed FFPP cervical sections. However for practical reasons only a representative selection have been shown here. All of the samples and cell types examined displayed similar infrared spectral characteristics as outlined above. 


\subsection{SR-FTIR spectroscopy of frozen cervical sections:}

FT-IR investigations into dewaxed FFPP sections yielded very good results, discriminating epithelial cells from invasive carcinoma, and even identifying pre-malignancy. However the increase in the absorption of the nucleic acid bands (1079 $\mathrm{cm}^{-1}$ and $1236 \mathrm{~cm}^{-1}$ ) with malignancy was not as dramatic as expected ${ }^{23}$. Also it would be desirable to be able to differentiate between basal cells, connective tissue and tumour cells. To determine if the tissue processing resulted in lower quality spectra, investigations were carried out using frozen tissue, mounted on MirrIR slides and air-dried. Fig. 5 shows the micrograph of the epithelial cells, basal cells and connective tissue selected, and the resulting FT-IR spectra are shown in Fig. 6. There is a dramatic improvement in the intensity of all the bands, and it is possible to differentiate between the tissue types.

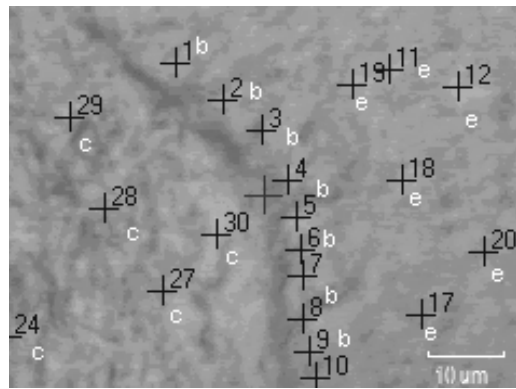

Fig. 5 Micrograph of cells selected from unprocessed tissue section ( $\mathrm{e}=$ epithelial cells, $\mathrm{b}=$ basal cells and $\mathrm{c}=$ connective tissue)

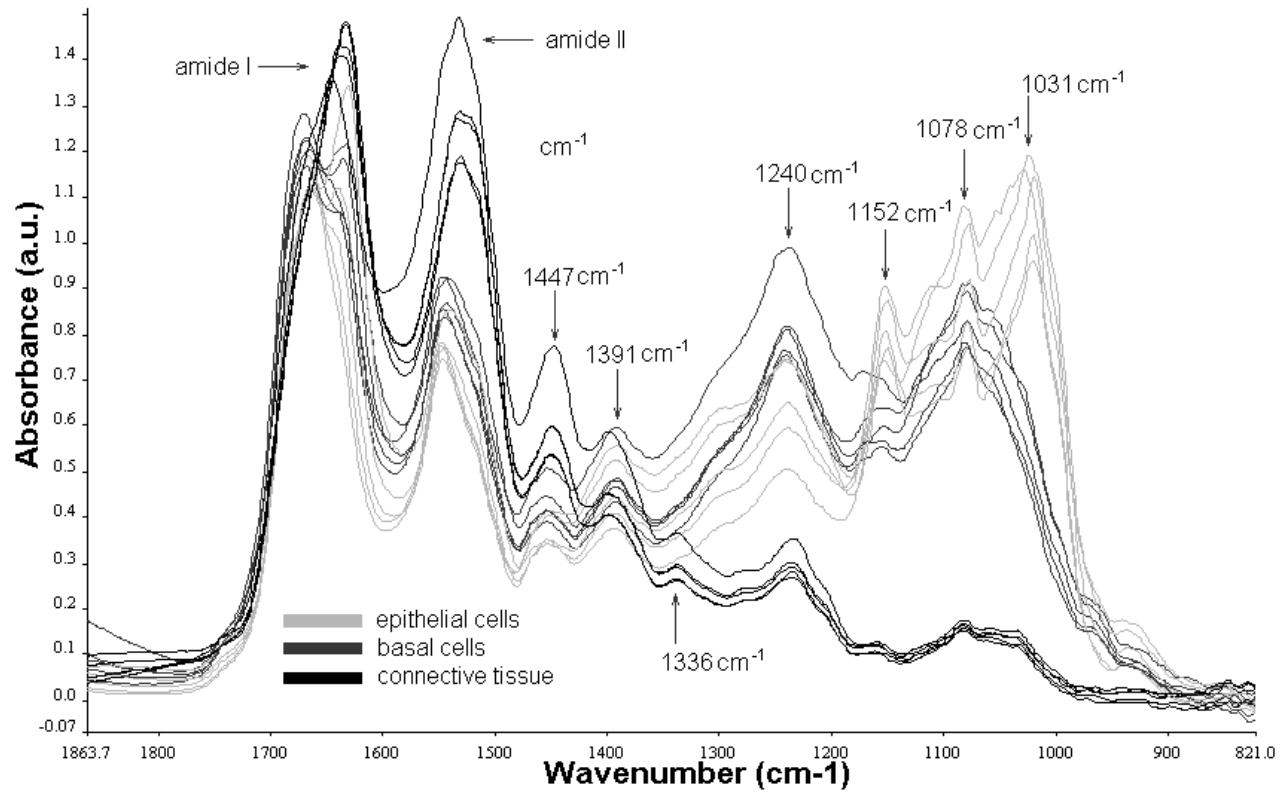

Fig. 6 FT-IR spectra from unprocessed tissue

Although there is a slight shift in wavenumber, epithelial cells still show strong absorption bands associated with glycogen $\left(1031 \mathrm{~cm}^{-1}\right.$ and $\left.1152 \mathrm{~cm}^{-1}\right)$. Nucleic acid contributions at $1078 \mathrm{~cm}^{-1}$ and $1240 \mathrm{~cm}^{-1}$ are also present. A noticeable feature of the spectra is the splitting of the amide I band into the finer structure of the $\beta$-pleated sheet structures $\left(1634 \mathrm{~cm}^{-1}\right)$ and $\alpha$-helical structures $\left(1666 \mathrm{~cm}^{-1}\right)$.

The basal cell spectra show a marked improvement in the intensity of the nucleic acid contributions at $1078 \mathrm{~cm}^{-1}$ and $1240 \mathrm{~cm}^{-1}$ compared with FFPP sections. This is an extremely encouraging result as it was the spectra of basal cells that were most closely related to that of invasive carcinoma. It is therefore not unreasonable to assume that a similar improvement in the level of absorption of invasive carcinoma frozen tissue sections could be expected in these regions. 
This in turn could accentuate the differences in nucleic acid contributions already observed in FFPP sections. Unprocessed tissue also reveals more detailed differences between basal cells and connective tissue. The amide II band of connective tissue has shifted down in frequency by $14 \mathrm{~cm}^{-1}$ (epithelial cells and basal cells amide II contribution occurs at $1546 \mathrm{~cm}^{-1}$ while connective tissue absorbs at $1532 \mathrm{~cm}^{-1}$ ) and is considerably more dominant. Also connective tissue displays considerably less absorption over the $1000-1100 \mathrm{~cm}^{-1}$ region, in contrast to both other tissue types. The band at $1336 \mathrm{~cm}^{-1}$ is as yet unassigned, however it is only present in connective tissue.

Unprocessed tissue appears to produce higher quality spectra and may have even more diagnostic capabilities than dewaxed FFPP sections. However due to the small numbers of these samples available, an unprocessed invasive carcinoma has not been obtained as yet

\subsection{Conventional FTIR spectroscopy of FFPP sections:}

Although the advantages of synchrotron FT-IR spectroscopy have already been outlined, such a source is not readily available for day-to-day measurements. Investigations were carried out on the FT-IR spectrometer available in-house in D.I.T (Perkin Elmer Spectrum GX). This is a single-beam, Michelson interferometer based, Fourier Transform infrared spectrometer/microscope. The radiation source is provided by a tungsten-halide lamp. Although the aperture is much larger $\left(50 \mu \mathrm{m}^{2}\right)$ than that achievable using synchrotron radiation, the spectra produced are comparable to those achieved at Daresbury Laboratory (not shown).

\subsection{Raman spectroscopy of FFPP cervical sections:}

A selection of the samples examined using FT-IR spectroscopy were also examined using Raman spectroscopy. Figure 7 shows the Raman spectra of connective tissue, basal cells and epithelial cells. Each of the different cell types has its own distinct signature spectrum. Raman assignments have been outlined in Table 2.

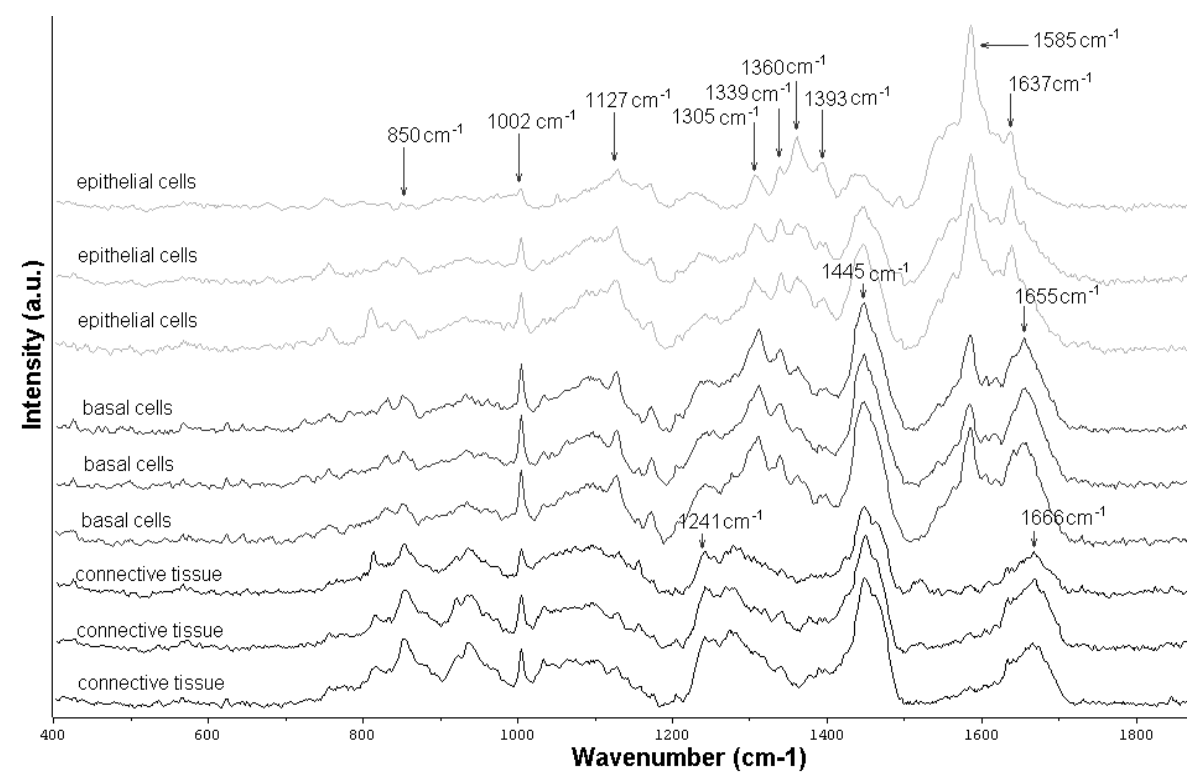

Fig. 7 Different cell types Raman

Fig. 8 shows the Raman spectrum of glycogen as measured by Choo-Smith et. al $2001^{24}$. Two distinctive peaks between $800-1000 \mathrm{~cm}^{-1}$, and a strong CC stretching component between $1000-1200 \mathrm{~cm}^{-1}$.

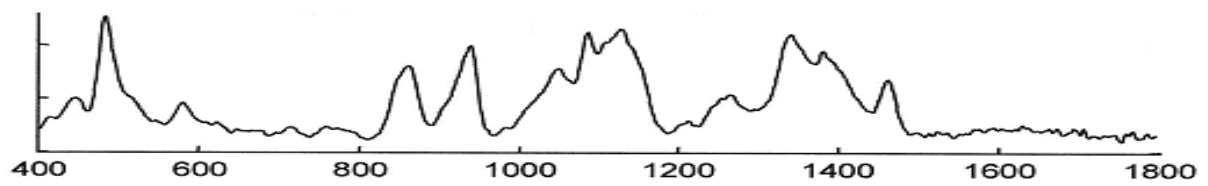


Fig. 8 Raman spectrum of glycogen (Choo-Smith et. al 2001)

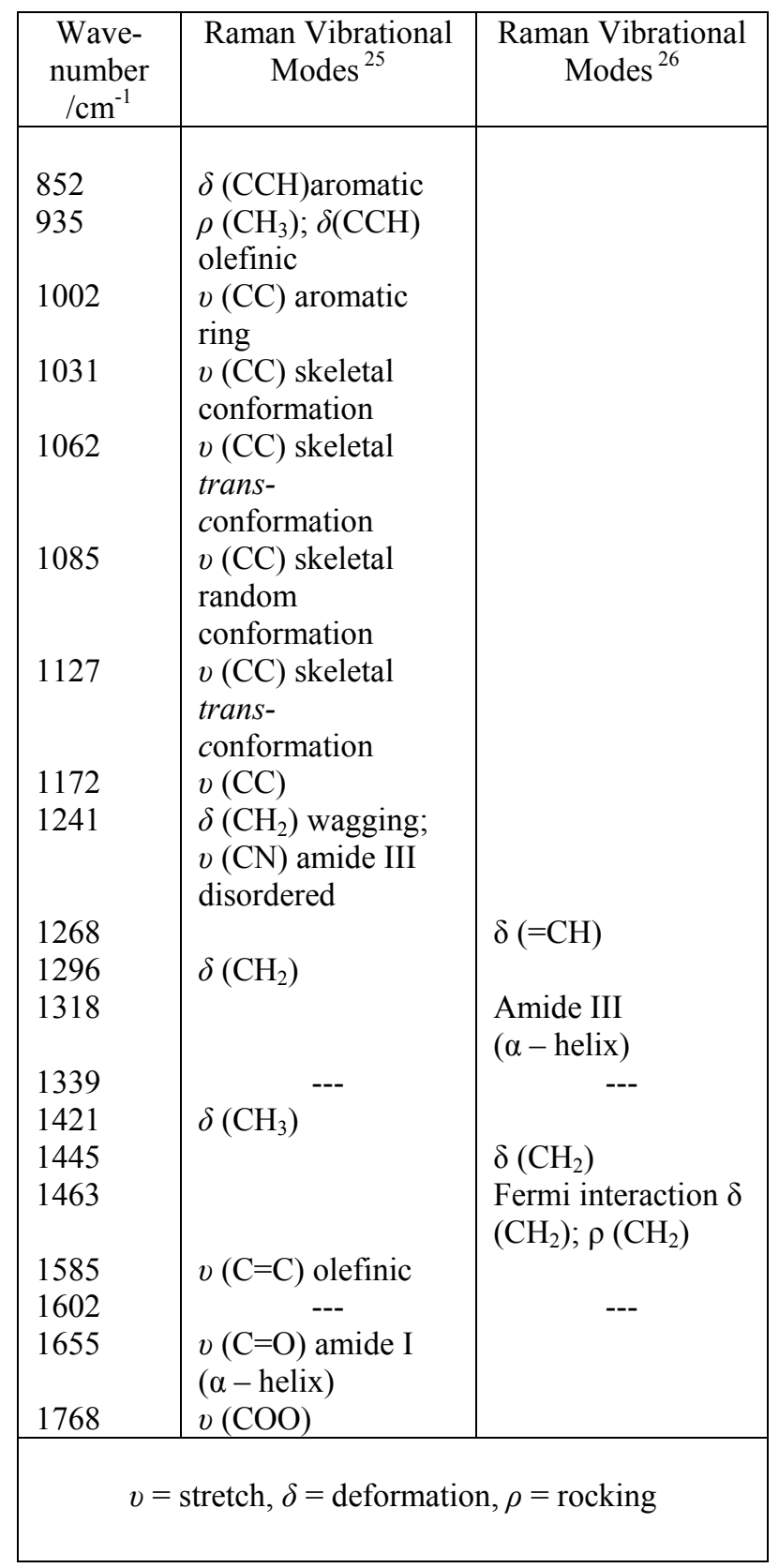

Table 2. Assignment of the Raman bands found in biological specimens

Fig. 9 shows Raman spectra collected from normal epithelial cells and invasive carcinoma (the same samples as were recorded using FT-IR spectroscopy Fig. 3). Spectra have been noise reduced, baseline corrected, lightly filtered and offset to facilitate clarity. Glycogen contributions (Fig. 8) are clearly visible in the spectra from the normal epithelial tissue. These bands arise at $852 \mathrm{~cm}^{-1}$ and $935 \mathrm{~cm}^{-1}$ and are due to $\mathrm{CCH}$ aromatic deformation, and $\mathrm{CCH}$ deformation respectively. There is a dramatic reduction in these glycogen bands $\left(852 \mathrm{~cm}^{-1}\right.$ and $\left.935 \mathrm{~cm}^{-1}\right)$ in the invasive carcinoma spectra, as well as a reduction in the CC stretching $\left(1085 \mathrm{~cm}^{-1}\right)$ which featured strongly in the glycogen spectra. There is also a reduction in the ringbreathing band at $1002 \mathrm{~cm}^{-1}$ in the malignant spectra. Kneipp et. al $2003^{13}$ has identified DNA Raman contributions at 728,782 , and $1575 \mathrm{~cm}^{-1}$, which are very similar to DNA spectra recorded by our group in a (not shown). The spectrum of invasive carcinoma displays increases in the bands at these frequencies, indicating an increase in the DNA content of malignant cells. Raman spectroscopy has corroborated the findings of the study using FT-IR spectroscopy.

The Raman spectra of pre-malignant tissue (CIN III) are shown in Fig. 10. As seen using SR-FTIR spectroscopy (Fig. 4), the Raman spectra display characteristics of both normal epithelial cells as well as invasive carcinoma as is to be expected.

Generally speaking it was found that Raman spectroscopy produced more detailed spectra, and hence appears more sensitive to changes in tissue composition than SR-FTIR spectroscopy. Naturally, Raman spectroscopy is intrinsically more sensitive to some bands than FTIR. However it is the higher spectral and spatial resolution that results in the more detailed spectra obtained using Raman spectroscopy. The spectral resolution of the Raman spectrometer $\left(2 \mathrm{~cm}^{-1}\right)$ is superior to the $8 \mathrm{~cm}^{-1}$ resolution of the FTIR. Also, the much larger sampling area of the FTIR spectrometer (although beneficial for sampling large areas) will also have the effect of broadening bands with the loss of spectral information. 


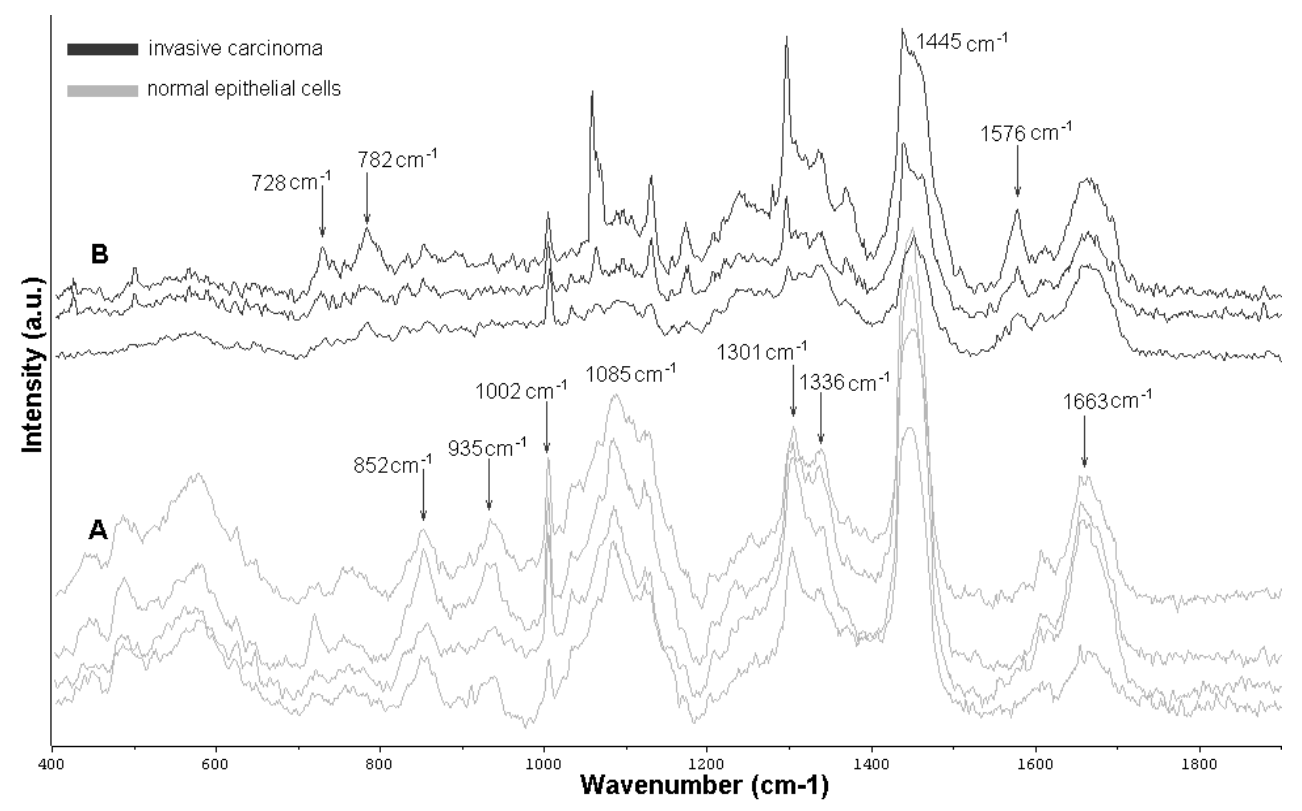

Fig. 9 Raman spectra of A) normal epithelial tissue B) invasive carcinoma. These are the same samples recorded using FT-IR spectroscopy in Fig. 6.6

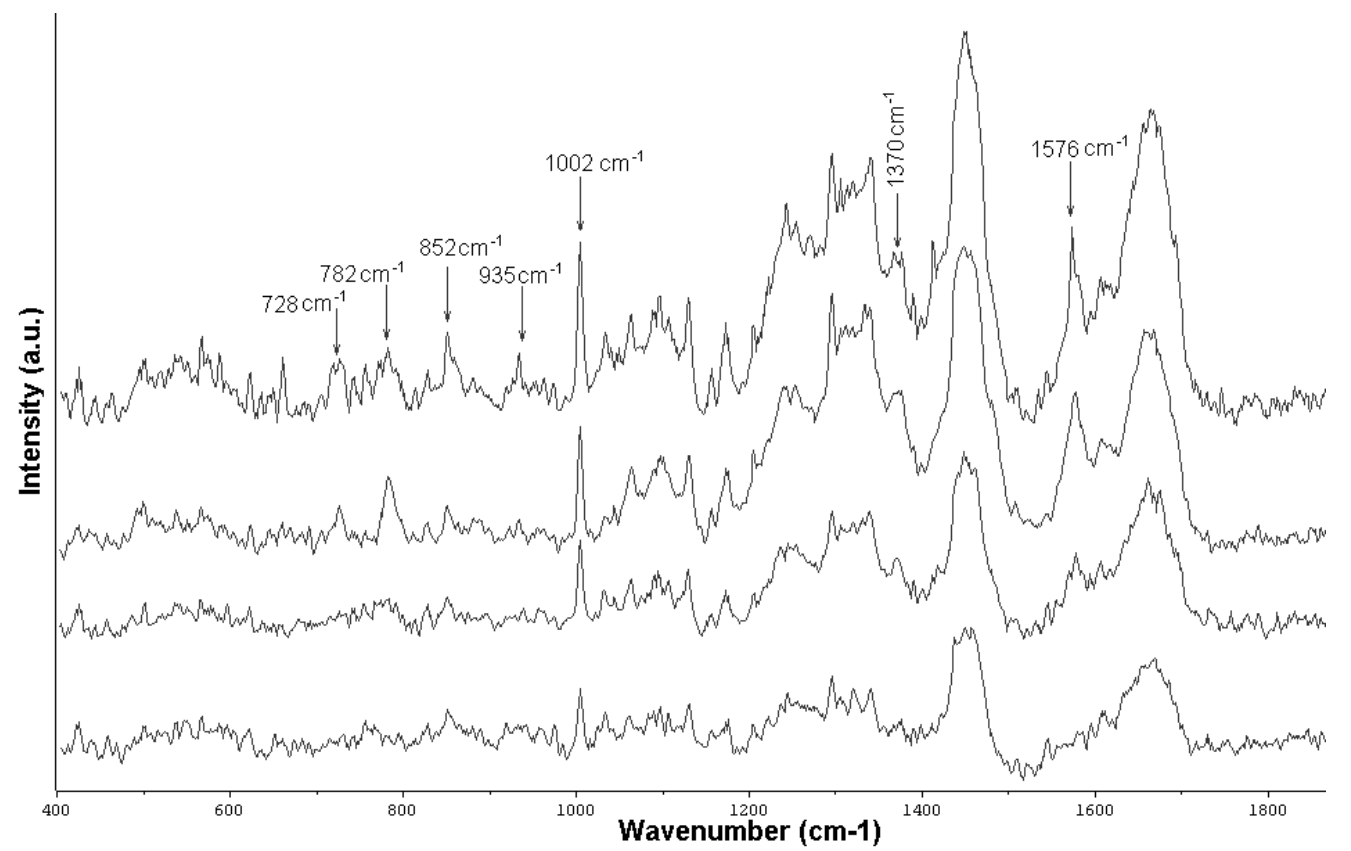

Fig. 10 Raman spectra of pre-malignant cervical tissue (CIN III) 


\section{CONCLUSIONS}

Fourier transform infrared spectroscopy has been shown to be an excellent method of differentiating between normal and cancerous tissues. It has highlighted some of the biochemical markers associated with cancerous tissue. The dramatic reduction in glycogen levels and the increase in nucleic acids with the onset of carcinogenesis has been clearly demonstrated. Raman spectroscopy was also able to highlight malignant and pre-malignant changes, although the biochemical changes may not be as apparent qualitatively as those seen using SR-FTIR spectroscopy. This detail in the spectra, coupled with a multivariate statistical package makes Raman spectroscopy a promising candidate for in-vivo measurements in the future. This study has also shown that dewaxed FFPP sections can indeed be utilised in a diagnostic capacity, to distinguish between invasive carcinoma and normal epithelial cells, and also to highlight pre-malignancy. Although dewaxed FFPP sections can highlight these biochemical changes, unprocessed tissue is better able to differentiate between different tissue types, and it is thought that the use of unprocessed sections will further accentuate the biochemical markers of cancer.

\section{ACKNOWLEDGEMENTS}

The authors would like to express sincere thanks to all the staff in the Histology Department in the NMH Holles St. for all their generous co-operation.

Thanks to Dr. Mark Tobin (SRS Daresbury) and the Access to Large Scale Facilities Programme for beamtime at Daresbury Laboratories.

The Focas Institute is funded under the Programme for Research in Third Level Institutions (PRTLI) administered by the Higher Education Authority (HEA)

\section{REFERENCES}

1. Twardowski J and Anzenbacher P (1994), "Raman and IR Spectroscopy in Biology and Biochemistry", Ellis Horwood, New York

2. Bozec L, Hammiche A, Tobin MJ, Chalmers JM, Everall NJ, Pollock HM (2002) "Near-field photothermal Fourier transform infrared spectroscopy using synchrotron radiation" Measurement Science \& Technology 13 (8): 1217-1222

3. Tobin, M., Rutten, F.,Chesters, M.,Chalmers, J., Symonds, I., Fisher, S., Allibone, R., Hitchcock, A. (2002) "Investigating the Potential for Infrared Microanalysis in Cancer Screening. European Clinical Laboratory": 20-22

4. Miller LM, Carr GL, Williams GP, Chance MR (1997) "Synchrotron infrared microspectroscopy as a means of studying chemical composition at a cellular level" Biophysical Journal 72 (2): TU445-TU445 Part 2

5. Jackson M, Sowa MG, Mantsch HH, (1997), "Infrared spectroscopy: a new frontier in medicine" Biophys Chem. 68 (1-3):109-25

6. Dukor RK, Liebman MN, Johnson BL. , (1998), "A new, non-destructive method for analysis of clinical samples with FT-IR microspectroscopy. Breast cancer tissue as an example" Cell Mol Biol (Noisy-le-grand). 44 (1):211-7

7. Wong PT, Wong RK, Caputo TA, Godwin TA, Rigas B. (1991) "Infrared spectroscopy of exfoliated human cervical cells: evidence of extensive structural changes during carcinogenesis." Proc Natl Acad Sci USA; 88(24):10988-92.

8. Yazdi H.M., Bertrand M.A., Wong P.T.T. (1996) "Detecting structural changes at the molecular level with FT-IR spectroscopy" Acta Cytologica, 40, 664

9. Chiriboga L, Xie P, Yee H, Vigorita V, Zarou D, Zakim D, Diem M (1998) "Infrared spectroscopy of human tissue. I. Differentiation and maturation of epithelial cells in the human cervix". Biospectroscopy 4(1):47-53.

10. Fung M.F.K., Senterman M., Eid P., Faught W.,. Mikhael N.Z, Wong P.T.T. (1997) "Comparison of FourierTransform Infrared Spectroscopic Screening of Exfoliated Cervical Cells with Standard Papanicolaou Screening" Gynecol. Oncol., 66, 10

11. Cohenford MA, Godwin TA, Cahn F, Bhandare P, Caputo TA, Rigas B. (1997) "Infrared spectroscopy of normal and abnormal cervical smears: evaluation by principal component analysis." Gynecol Oncol. 66(1):59-65.

12. Shaw RA, Guijon FB, Paraskevas M, Ying SL, Mantsch HH (1999) "Infrared spectroscopy of exfoliated cervical cell specimens. Proceed with caution" Anal. Quantitat. Cytol. Histol., 21, 292 
13. Kneipp J, Schut TB, Kliffen M, Menke-Pluijmers M, Puppels G (2003) "Characterization of breast duct epithelia: a Raman spectroscopic study" Vibrational Spectroscopy 32 (1): 67-74

14. Gniadecka M, Wulf HC, Nielsen OF, Christensen DH, Hercogova J (1997) "Distinctive molecular abnormalities in benign and malignant skin lesions: Studies by Raman spectroscopy" Photochemistry and Photobiology 66 (4): $418-423$

15. Kaminaka S., Yamazaki, H. I., T.; Kohda, E.; Hamaguchi, H. (2001). "Near-Infrared Raman Spectroscopy of human lung tissues; possibility of molecular-level cancer diagnosis" Journal of Raman Spectroscopy 32: 139-141

16. Mizuno A, Hitajima K., Kawauchi K, Muraishi S, Ozaki Y (1994). "Near-Infrared Fourier-Transform RamanSpectroscopic Study of Human Brain-Tissues and Tumors" Journal Of Raman Spectroscopy 25(1): 25-29

17. Hawi S.R., Cambell W. B., Kajdacsy-Balla A., Murphy R., Adar F., Nithipatikom K. (1996). "Characterization of normal and malignant hepatocytes by Raman Microspectroscopy" Cancer Letters 110: 35-40.

18. Crow P, Kendall C, Uff J, Gilbert H, Persad R, Wright M (2003) "Optical diagnostics in prostate cancer: The use of Raman spectroscopy to differentiate between different prostatic pathologies in vitro" Journal of Urology 169 (4): 1618 Suppl.

19. Mahadevan-Jansen A., M. F. M., Nirmala Ramanujam, Anais Malpica, Sharon Thomsen, Urs Utzinger and Rebecca Richards-Kortum (1998). "Near-Infrared Raman Spectroscopy for In Vitro Detection of Cervical Precancers" Photochemistry and Photobiology 68(1): 123-132.

20. Utzinger U, Mahadevan-Jansen A, Hinzelman D, Follen M, Richards-Kortum R (2001) "Near Infrared Raman Spectroscopy for In Vivo Detection of Cervical Precancers” Applied Spectroscopy 55 (8) 955.

21. Neviliappan S, Fang Kan L, Tiang Lee Walter T, Arulkumaran S, Wong PT. (2002) "Infrared spectral features of exfoliated cervical cells, cervical adenocarcinoma tissue, and an adenocarcinoma cell line (SiSo)" Gynecol Oncol. 85(1):170-4.

22. Naumann D (2001) "FT-infrared and FT-Raman spectroscopy in biomedical research" Applied Spectroscopy Reviews 36 (2-3): 239-298

23. Sindhuphak R, Issaravanich S, Udomprasertgul V, Srisookho P, Warakamin S, Sindhuphak S, Boonbundarlchai R, Dusitsin N. (2003) "A new approach for the detection of cervical cancer in Thai women." Gynecol Oncol; 90(1): 10-4.

24. Choo-Smith LP, Maquelin K, van Vreeswijk T, Bruining HA, Puppels GJ, Ngo Thi NA, Kirschner C, Naumann D, Ami D, Villa AM, Orsini F, Doglia SM, Lamfarraj H, Sockalingum GD, Manfait M, Allouch P, Endtz HP (2001) "Investigating microbial colony heterogeneity by vibrational spectroscopy" Appl Environ Microbiol. 67(4):1461-9

25. Barry BW, Edwards H.G.M., Williams AC "Fourier transform Raman and infrared vibrational study of human skin: Assignment of spectral bands" (1992). Journal Of Raman Spectroscopy 23(11): 641-645.

26. Lakshmi R. Jyothi, V. B. K., C. Murali Krishna,J. G. R. Solomon,G. Ullas,P. Uma Devi "Tissue Raman Spectroscopy for the Study of Radiation Damage: Brain Irradiation of Mice” (2002) Radiation Research 157(2): 175182.

* eoghanofaolain@eircom.net; phone +353 1 4027931; fax +353 1 4027901; http://focas.dit.ie/ 